Illinois State University

ISU ReD: Research and eData

Theses and Dissertations

$3-12-2021$

\title{
Evaluating The Multi-Level Community Effects Of Root Hemiparasites In Northern Illinois
}

Anna Marie Scheidel

Illinois State University, ascheidel@yahoo.com

Follow this and additional works at: https://ir.library.illinoisstate.edu/etd

Part of the Biodiversity Commons

\section{Recommended Citation}

Scheidel, Anna Marie, "Evaluating The Multi-Level Community Effects Of Root Hemiparasites In Northern Illinois" (2021). Theses and Dissertations. 1410.

https://ir.library.illinoisstate.edu/etd/1410

This Thesis is brought to you for free and open access by ISU ReD: Research and eData. It has been accepted for inclusion in Theses and Dissertations by an authorized administrator of ISU ReD: Research and eData. For more information, please contact ISUReD@ilstu.edu. 


\section{EVALUATING THE MULTI-LEVEL COMMUNITY EFFECTS OF ROOT HEMIPARASITES IN NORTHERN ILLINOIS}

\section{ANNA MARIE SCHEIDEL}

\section{Pages}

Root hemiparasites are green plants that tap into a neighboring plant's water-filled xylem to acquire inorganic nutrients, which can lead to an accumulation of nutrients in hemiparasite biomass. I performed an observational field study at Nachusa Grasslands and Franklin Creek State Natural Area (Lee County, IL) in 2019 to investigate how the presence of five root hemiparasites (Aureolaria grandiflora (Benth.) Pennell, Agalinis tenuifolia (Vahl) Raf., Castilleja sessiliflora (Pursh), Dasistoma macrophylla (Nutt.) Raf., Pedicularis canadensis L.) affects their communities through the (a)keystone species hypothesis, that hemiparasites will increase measures of diversity by altering competition among surrounding plant species, (b) ecological engineer hypothesis, in that hemiparasites redistribute nutrients via the hemiparasite's biomass, and (c) the life history hypothesis, in that annual and perennial hemiparasites differ in the quality of their leaf litter. If the hemiparasites do have a community effect, I predict (a) in areas where hemiparasites are present, plant diversity will be higher, (b) the soil nutrient content will be higher in the immediate presence of hemiparasite leaf litter than in hemiparasite absence, and (c) annual hemiparasite leaf litter will have higher nitrogen content than that of perennial hemiparasites'. C. sessiliflora was associated with higher plant diversity (a) and higher soil phosphate levels (b). Total number of plant species present in the plots was curvilinearly related to the percent abundance of $C$. sessiliflora. Other soil nutrient level differences can be tied to the 
site of each hemiparasite population, not the presence of the hemiparasites. Not enough material was collected to test hypothesis (c).

KEYWORDS: prairie; ecology; root hemiparasites; community ecology; Illinois; nutrient

cycling 


\title{
EVALUATING THE MULTI-LEVEL COMMUNITY EFFECTS OF ROOT HEMIPARASITES IN NORTHERN ILLINOIS
}

ANNA MARIE SCHEIDEL

\author{
A Thesis Submitted in Partial \\ Fulfillment of the Requirements \\ for the Degree of \\ MASTER OF SCIENCE \\ School of Biological Sciences \\ ILLINOIS STATE UNIVERSITY
}

2021 
C 2021 Anna Marie Scheidel 


\title{
EVALUATING THE MULTI-LEVEL COMMUNITY EFFECTS OF ROOT HEMIPARASITES IN NORTHERN ILLINOIS
}

\author{
ANNA MARIE SCHEIDEL
}

COMMITTEE MEMBERS:

Victoria A. Borowicz, Chair

Steven A. Juliano

Meghan Midgley 


\section{ACKNOWLEDGMENTS}

I would first like to thank V. Borowicz for her unending support and guidance throughout the process of researching and writing this thesis during my time as a graduate student. Her door and Zoom were always open when I needed help. I would like to thank my committee members S. Juliano and M. Midgley for their support, and M. Midgley for her guidance and the use of her facilities for my soil analyses. I'd like to thank T. Martin, J. Howard, K. Cazzato, J. Edmundson, E. Berry, and A. Morgan for their assistance in my field and lab work. I would like to thank everyone at Nachusa Grasslands, including E. Bach, B. Kleiman, C. Considine, for all their support and all that they've taught me about prairie restoration. Thank you to the residents of Nachusa Grasslands for bison-blocking me whenever I wanted to visit the Eight Oaks prairie unit, especially Scott- your presence was both inspiring and inconvenient. Finally, I'd like to thank my family for providing me with unfailing support and continuous encouragement throughout my years of study. This accomplishment would not have been possible without them. This research was funded by Phi Sigma Biological Honors Society Beta Lambda Chapter, Illinois State University Graduate School, and Friends of Nachusa Grasslands.

A.M.S. 


\section{CONTENTS}

Page

ACKNOWLEDGMENTS

CHAPTER I: INTRODUCTION 1

Parasitic Plants

Keystone Species Hypothesis $\quad 2$

Ecosystem Engineer Hypothesis 3

Life History Hypothesis $\quad 5$

Research Goals $\quad 5$

$\begin{array}{ll}\text { CHAPTER II: METHODS } & 7\end{array}$

$\begin{array}{ll}\text { Study Species } & 7\end{array}$

$\begin{array}{ll}\text { Field Sites } & 8\end{array}$

Vegetation Surveys $\quad 9$

Ion Exchange Resin Strips 10

$\begin{array}{ll}\text { Leaf Litter } & 11\end{array}$

Data Analysis $\quad 11$

$\begin{array}{ll}\text { CHAPTER III: RESULTS } & 13\end{array}$

$\begin{array}{ll}\text { Vegetation Surveys } & 13\end{array}$

$\begin{array}{ll}\text { Soil Nutrients } & 14\end{array}$

$\begin{array}{ll}\text { Leaf Litter } & 15\end{array}$

CHAPTER IV: DISCUSSION 16

Keystone Species Hypothesis 16

Ecosystem Engineer Hypothesis 17 
$\begin{array}{ll}\text { Site History } & 19\end{array}$

Life History Hypothesis $\quad 21$

Use of Root Hemiparasites in Restoration Practices 22

CHAPTER V: CONCLUSION 24

$\begin{array}{ll}\text { REFERENCES } & 25\end{array}$

APPENDIX A: TABLES $\quad 32$

APPENDIX B: FIGURES 


\section{CHAPTER I: INTRODUCTION}

\section{Parasitic Plants}

Most vascular plants use photosynthesis to create sugars and obtain nutrients via their root systems from the surrounding soil. Nutrients such as nitrogen, phosphorus, and potassium are essential to plant growth, reproduction, and basic cell function (Verhoeven \& Schmitz 1991, Wang et al. 2007). Plants without adequate access to these nutrients have evolved alternative strategies of acquisition. Through carnivory, plants such as pitcher plants and flytraps acquire nitrogen by digesting insects that they have ensnared for nutrients (Lloyd 1942, Dixon et al. 1980). Parasitism is an alternative strategy, in which the parasitic plant develops a structure called a haustorium either on its roots or stem by which it attaches onto another plant's root or stem (Press \& Phoenix 2005). These haustoria grow into a host plant's vascular system, either to extract sugars from the phloem or to take water dissolved nutrients, and possibly organic compounds that are transported by the xylem (Press \& Phoenix 2005, Ameloot et al. 2005, Pywell et al. 2004).

Parasitic plants are in 16 families and are found almost all over the world (Musselman \& Press 1995). One of the most wide-spread families, Orobanchaceae, includes holoparasites, which are obligate parasites that will not survive without a host attachment, and hemiparasites, which are partially parasitic. The latter still have the defining haustoria, but also photosynthesize. These parasites usually tap into their host's stem or root xylem in order to acquire a continuous flow of water (Press \& Phoenix 2005). Hemiparasites can be further classified into obligate hemiparasites, which cannot survive and reproduce without a host, and facultative hemiparasites, which are able to survive and reproduce without having haustoria attaching onto a host plant. Although capable of free-living, facultative hemiparasites are almost 
always found in the wild attached to another plant. Press et al. (1999), in a greenhouse

experiment, found that hemiparasites will form attachments to hosts if present even if they have the greatest biomass when no haustoria are formed. In hemiparasites such as Rhinanthus minor L., their stomata might remain closed according to some studies (Jiang et al. 2003). If the hemiparasite attaches to a host, its stomata will open and remain so, the constant transpiration activity causing the stomata to act as a near constant pump in order to extract the host plant's xylem contents (Jiang et al. 2003). Due to the constant pumping of water from the host plant's xylem and out of the hemiparasite's leaves via transpiration, some hemiparasites accumulate a surplus of macro- and micronutrients in biomass (Lamont 1983, Pate 1995).

Extraction of resources via the haustoria results in a direct negative effect on the host plant, typically measured in reduced biomass, and this can depress population abundance (Press \& Phoenix 2005, Ameloot et al. 2005, Pywell et al. 2004). Change in population abundances in turn can affect the presence and abundances of species in a community. Several effects at the level of the community have been postulated.

\section{Keystone Species Hypothesis}

Hemiparasites frequently are associated with change in measures of diversity (Ameloot et al. 2005, Pywell et al. 2004), e.g., by altering the numbers of species, also referred to as species richness, or changing representation of subordinate species, known as species evenness (Spasojevic \& Suding 2011). The exact mechanisms by which hemiparasites have these effects on diversity are not well known, but models propose top-down and bottom-up effects (Spasojevic \& Suding 2011, Suding et al. 2013). The first model focuses on the direct effects of parasitism and proposes that by debilitating hosts, hemiparasites release subordinate species 
from competition (Těšitel et al. 2017). If dominant species in the community are more frequently parasitized, or less tolerant of parasitism than competitors, they will grow less, leaving more resources for plants that are normally out-competed by such dominant species, resulting in greater relative abundance of existing species or establishment of species otherwise excluded through competition. By reducing competition, hemiparasites can alter the diversity of their surrounding community, leading some to suggest their role as a keystone species (Hartley et al. 2015). Keystone species are identified as species that, while not the most abundant in numbers, have a disproportionate role in maintaining diversity within the surrounding community (Paine 1966). The role of keystone species in natural communities can be identified through manipulative experiments, such as the classic study of intertidal invertebrates by Paine (1966) and removal or addition of hemiparasites in experimental plots (Marvier 1998, Joshi et al. 2000). However observational studies that compare unmanipulated communities with vs. without hemiparasites can demonstrate whether the impact of hemiparasites is consistent with predictions of a keystone effect.

\section{Ecosystem Engineer Hypothesis}

Nutrient-rich leaf litter is posited to enrich the soil (Quested et al. 2003) and thereby have cascading effects on the surrounding community. Quested et al. (2002) found that sub-arctic hemiparasitic leaf litter had significantly higher percent nitrogen content compared to neighboring dwarf shrubs, graminoids, and forbs. This excess of nutrient build-up has been shown to alter the rate of nutrient cycling in the soil (Quested et al. 2002) as well as influence species diversity of soil microbes and plants (Fisher et al. 2013). The second model considers

hemiparasites' influence via soil nutrients deposited from leaf litter. Recall that the open stomata 
act as a constant pump allowing hemiparasites to intake water and dissolved minerals. The water is consistently transpired out, but the nutrients accumulate within the hemiparasite's biomass. By the end of the growing season when the plants senesce, the hemiparasite litter releases an abundance of nutrients back into the soil, promoting growth of nutrient-processing bacteria that decompose more recalcitrant litter of other plants (Quested et al. 2002, 2005; March \& Watson 2009; Spasojevic \& Suding 2011; Demey et al. 2013; Fisher et al. 2013). These effects of hemiparasite litter are presumed to be local and may create patches of higher nutrient soil. By increasing availability of nutrients for other plants, hemiparasites modify the habitat and thus act as ecosystem engineers (Jones et al. 1994). For example, a mesocosm experiment (Bardgett et al. 2006) studied how the leaf litter of hemiparasitic Rhinanthus minor influenced the microbial structure of the soil. The nutrient-enriched litter after decomposition enriched the soil, slightly, but significantly, reduced the fungi to bacteria ratio. Fungi tend to be more abundant in nutrientpoor environments and bacteria in nutrient-rich environments (Bardgett 2005), so an influx of nutrients via increased nitrogen mineralization in previously non-fertile soil enabled the bacteria to flourish. Hemiparasites are commonly found in low-nutrient sites where nutrient acquisition via parasitism will have strong, negative effects on host plants (Matthies 1995). At the same time, nutrient release to the soil via the leaf litter route will have strong positive effects on nutrient-limited plants. However, these effects from leaf litter have mostly been studied in subarctic systems (Quested et al. 2002, Quested et al. 2003) which have limited nutrients in their soils (Berendse and Jonasson 1992; Callaghan and Jonasson 1995). Hemiparasites’ role as an ecosystem engineer has not been extensively studied in prairie grasslands, an ecosystem known for its rich soil organic matter (SOM) content, nor have potential differences in nutrient 
allocation by hemiparasites with different life histories been evaluated. These gaps in our knowledge are the focus of my thesis.

\section{Life History Hypothesis}

Hemiparasites may be annuals, which only live for a single growing season and then die, or longer-lived perennials, which have two or more growing seasons and possibly more than one reproductive event. These different life histories should affect how hemiparasites allocate resources and how they interact with other plants. Allocation of resources into reproduction, growth, and predator avoidance is referred to as the life cycle strategy (Harper \& Ogden 1970). Because annual hemiparasites die following seed production, their leaves may contain excess minerals at senescence. By contrast, perennial hemiparasites invest in underground storage to survive the winter season and may withdraw excess nutrients from leaves before they senesce (Harper \& Ogden 1970). Therefore, annual and perennial hemiparasites may differ in the strength of their habitat moderation as ecosystem engineers depositing senescent leaves.

\section{Research Goals}

My thesis focuses on two aspects of root hemiparasites: (1) how hemiparasites affect the surrounding plant community; and (2) how the life history of the hemiparasite species influences its depth of impact on the surrounding community via soil nutrient availability. Through observational field studies I tested three hypotheses.

The keystone hypothesis posits that hemiparasites will increase measures of diversity by altering competition among surrounding plant species. This hypothesis assumes that dominant plant species are more commonly parasitized or more strongly affected 
by the parasitic attachment. I predicted that in areas where hemiparasites are present, plant diversity will be higher, as measured by the number of plant species present, evenness, and/or total percent cover of functional groups.

The ecosystem engineer hypothesis posits that hemiparasites redistribute nutrients via the hemiparasite's biomass. If the hemiparasites produce more nutrient-rich leaf litter that decomposes more rapidly than other species, the soil immediately surrounding the plant should have higher nutrient content than soil more distant from the hemiparasite. I predict the soil nutrient content, measured as nitrate, ammonium, and phosphate, will be higher in the immediate presence of hemiparasite leaf litter.

If the presence of hemiparasites does impact the surrounding plant community and soil, then the responses should also depend on the life history of the hemiparasite. The life history hypothesis posits that due to different life histories, annual and perennial hemiparasites differ in the quality of their leaf litter. Because perennial hemiparasites translocate nutrients for the next year's growth I predicted they will produce senescing leaf litter that is lower in mineral content compared to annual hemiparasites that die at the end of the season. This difference in nutrient allocation would also be expressed as a lower C:N ratio for senesced annual hemiparasite litter.

These experimental observations will assist land managers in deciding if they should include root hemiparasites in their restored prairie plantings, which plant species they might choose, and optimal relative abundance to include in their seed mix. 


\section{CHAPTER II: METHODS}

\section{Study Species}

Agalinis tenuifolia (Vahl) Raf. (slenderleaf false foxglove), is a summer annual hemiparasite found over the eastern US west through the Plains states and north through Manitoba (USDA, NRCS 2020). Found in moist to dry soil in prairies, savannas, and woodlands, A. tenuifolia grow erect to $60 \mathrm{~cm}$ (Plant Finder Staff, Missouri Botanical Garden ;2020). They tend to be indiscriminate when parasitizing a host and are more likely to be selfcompatible (Man \& Musselman 1981). A. tenuifolia performs best when it creates haustoria connecting it to a host (Man \& Musselman 1981).

Dasistoma is a genus with only one species, D. macrophylla (Nutt.) Raf., also known as mullein foxglove. This annual hemiparasite, which prefers dry and shaded conditions, was originally described as an obligate parasite of sugar maples and American elm. They have since been observed attaching onto some oak and other tree species. (Piehl 1962)

Aureolaria grandiflora (Benth.) Pennell is an erect perennial hemiparasite found throughout the U.S. Midwest region, grows up to $150 \mathrm{~cm}$, and, like D. macrophylla, also parasitizes trees. Also known as large-flowered yellow false foxglove, it is commonly found in dry, upland woods. (Department of Botany, Wisconsin State Herbarium, University of Wisconsin-Madison (2020)

The genus Castilleja consists of around 200 species commonly known as Indian Paintbrush. They are known to inhabit open meadows, spanning across the United States, usually parasitizing legumes and short grasses. Castilleja sessiliflora (Pursh) is an Illinoisnative hemiparasite that grows under full sun in low-nutrient soils. While reported to prefer 
short grasses and sedges, it is more of a generalist when finding a host. (Wilhelm \& Rericha 2017)

Pedicularis, referred to as lousewort or betony, is a widespread genus with about 400 species (Schneider \& Stermitz 1990). They tend to parasitize asters and native grasses.

DiGiovanni et al. (2017) found that Pedicularis canadensis L., commonly found in mesic and dry black soil prairies, significantly decreased the dry biomass of partridge pea plants when parasitizing them.

\section{Field Sites}

Nachusa Grasslands is a 4,000+ acre nature preserve located in both Lee and Ogle Counties, IL, mainly comprised of restored prairies and woodlands. It is privately owned and maintained by The Nature Conservancy. I obtained a research permit in January 2019 to evaluate the populations of four hemiparasite species: Agalinis tenuifolia (located at Bluestem Bottoms, a wetland/prairie within Nachusa Grasslands, 41.888683, -89.353461), Castilleja sessiliflora (Senger, dry, upland prairie, 41.900937, -89.370542), Pedicularis canadensis (Eight Oaks, mesic tallgrass prairie, 41.884242, -89.355778), and Aureolaria grandiflora (Tellabs, woodland, 41.894058, -89.366950).

Franklin Creek Preserve is located about $6 \mathrm{~km}$ south of Nachusa Grasslands. I obtained an additional research permit in June 2019 to evaluate the population of an annual root hemiparasite Dasistoma macrophylla (41.840344, -89.314942) growing in the woodlands. All five hemiparasite populations can be seen on a map in Fig. 1.

Due to difficulty locating the hemiparasites, I established plots at each site when the target hemiparasite was in full bloom. $C$. sessiliflora and $P$. canadensis were identified in late 
May, D. macrophylla and A. grandiflora were identified in late June, and A. tenuifolia was identified in early September. At each site, I established 10 paired 1-m² plots. A control plot was established in the nearest hemiparasite-free area at least five meters away from its experimental plot. For plots with the hemiparasite, no other hemiparasites could occur within $0.5 \mathrm{~m}$ of the plot in at least 2 cardinal directions. This was to ensure soil nutrient levels could be measured at different distances away from the hemiparasite without input from additional individuals. The control plots had no hemiparasites within the plot and in the surrounding 0.5 meters.

\section{Vegetation Surveys}

I tested the keystone hypothesis using vegetation survey data taken during Spring/Summer 2019. I surveyed all plots located in the Senger Unit, which has populations of C. sessiliflora, between June 14 and 29. Plots in Eight Oaks Unit, where P. canadensis grows, were surveyed between July 11 and August 5. I only surveyed these two hemiparasite populations because they both grow in prairie habitats and I am more familiar with the plant species. I recorded the total number of plants along with percent cover of each species within the plots. I included the coefficient of conservation for each species identified in the field using the values from Flora of the Chicago Region (2017). This is referred to as a 'C value,' ranges from $0-10$, and is used to estimate how likely a native plant will appear in a remnant ecosystem, pertaining to the Chicago region. Using the C-values, I calculated the Floral Quality Indices (FQI) for each plot. 


\section{Ion Exchange Resin Strips}

To test the effects of hemiparasite litter on soil minerals, I charged cation and anion exchange resin strips $(2.5 \mathrm{~cm} \times 10 \mathrm{~cm})$ using the Kellogg LTER protocol found on their website: https://lter.kbs.msu.edu/protocols/105. I made one modification: during the five-hour charging process I changed the sodium bicarbonate bath every 2.5 hours instead of every hour. I cut a small hole punch at the top of each strip and attached a colored zip tie to make retrieval easier.

Between August 31- October 26, varying due to different senescence timing, I inserted ion exchange resin strips into the ground at each plot for each species using a $25 \mathrm{~cm}$ beekeeping prybar in order to minimize soil disturbance. I inserted strips for the $C$. sessiliflora plots on August 31, P. canadensis and D. macrophylla on October 19, and A. grandiflora on October 26. One cation strip and two anion strips make up one 'set' of strips. I placed one set in the center of each control plot. Two sets were placed at the crown of the hemiparasite in opposite directions, two sets at $25 \mathrm{~cm}$ away from the crown, and two sets at $50 \mathrm{~cm}$ away from the crown. I buried the strips in the soil with the top edge at the surface and the zip ties visible for eventual retrieval. I slightly disturbed the ground when I had to push aside detritus to prevent it from getting inserted into the ground along with the resin strips. I was not able to insert strips at the A. tenuifolia plots due to flooded grounds.

I left the strips in the ground for five weeks, except for A. grandiflora which I extracted after four weeks to avoid shotgun deer hunting season. I extracted strips for the $C$. sessiliflora plots on October 5, P. canadensis and D. macrophylla on November 23, and A. grandiflora on November 23. After removing them, I placed the strips in labeled plastic bags and refrigerated them until I extracted the charges following the Kellogg protocol. From each set of ion strips, the 
cation was used to extract ammonium, one anion was used for nitrate extraction, and the second anion was used to measure phosphate.

I kept the ion extracts frozen until January 2020, and then analyzed them in the soil ecology lab at The Morton Arboretum in Lisle, IL using microplate protocols adapted from Sims et al. (1995), Hood-Nowotny et al. (2010), and Hedley et al. (1982).

\section{Leaf Litter}

To test my life history hypothesis, I compared leaf litter from annual and perennial hemiparasites. When the hemiparasites in plots were in flower, 4 to 5 leaves were collected from a conspecific within a $1 \mathrm{~m}$ radius of each experimental plot. I collected $P$. canadensis on May

$20^{\text {th }}$, C. sessiliflora on May $23^{\text {rd }}, D$. macrophylla on July $23^{\text {rd }}, A$. grandiflora on August $25^{\text {th }}$, and A. tenuifolia on September $15^{\text {th }}$. When the leaves from each species began senescing, I collected an equal number of leaves in the same areas, from different conspecifics than previously sampled. The leaves were dried at $60^{\circ} \mathrm{C}$ and stored at room temperature for later analysis. Senesced leaves could not be collected from two species: D. macrophylla due to herbivory, and A. tenuifolia due to unanticipated rapid abscission. During December, the leaf litter samples were further dried with liquid nitrogen, ground, weighed, and analyzed for total carbon and total nitrogen using a Vario EL cube at The Morton Arboretum in Lisle, IL under the supervision of Dr. Meghan Midgley. The samples were destroyed in the process.

\section{Data analysis}

Vegetation Surveys. All statistical analyses were conducted using SAS 9.4. Community metrics for $C$. sessiliflora and P. canadensis sites were analyzed separately. For C. sessilifora, I 
conducted two multivariate analysis of variance (MANOVA) with hemiparasite (present/absent) as main effect. The first analyzed percent cover by graminoids, legumes, and non-legume forbs as response variables and the second analyzed the number of species in each functional group. Due to many zero values for legumes, I combined forbs and legumes in similar analyses for $P$. canadensis. In the event of a significant effect on one of these community metrics I followed up with analysis of variance of the floristic quality index for each plot as response variable and hemiparasite presence/absence as main effect.

Ion Exchange Resin Strips. I analyzed the nitrate, ammonium, and phosphate absorbed $\left(\mu \mathrm{g} / \mathrm{cm}^{2}\right)$ from ionic strips as response variables with repeated measures, with distance from the crown $(0,25,50 \mathrm{~cm})$ as within-subjects repeated factor and hemiparasite as the between-subjects factor. This was followed by MANOVA of nitrate and phosphate in plots from the C. sessiliflora site with hemiparasite (present/absent) as the main effect.

Carbon:Nitrogen. To test the life history hypothesis I planned to compare the Carbon:Nitrogen content of senesced leaves of annual hemiparasites to perennial hemiparasites. The senesced leaves of both annual hemiparasites, A tenuifolia and D. macrophylla, could not be obtained due to unanticipated rapid senescence and heavy herbivory, respectively. An analysis of variance test was used to test the effect of timing of collection- before or after senescence- in the perennial species. 


\section{CHAPTER III: RESULTS}

\section{Vegetation Surveys}

Castilleja sessiliflora. A MANOVA was performed testing the effect of the hemiparasite C. sessiliflora (present/absent) on the total percent cover of three plant functional groups: forbs, legumes, and graminoids. Despite numerous transformations the legumes dataset did not follow normal distribution, but a log transformation most nearly met the assumption ( $\mathrm{W}=0.0136)$. The presence of $C$. sessiliflora did not significantly affect percent cover of the three functional groups ((Pillai's trace $=0.0586, \mathrm{~F}_{[3,16]}=0.33, P=0.8025$; Fig. 2).

Although presence of the hemiparasite did not affect this mid-season measure of abundance, $C$. sessilifora presence significantly affected species composition (Fig. 3; Pillai's Trace $=0.397, P=0.0397$ ) with forbs largely responsible for this significant effect (standardized canonical coefficients: forbs $=0.9165$, graminoids $=0.5675$, legumes $=0.5142$ ). There were on average 5.3 more species of forbs present in the plots with the hemiparasite than without $\left(F_{3,18}=\right.$ $3.51, P=0.0064)$.

To better interpret this effect of $C$. sessilifora on the community I followed up with an analysis of variance using the FQI values in the presence/absence of C. sessiliflora (Fig. 4). Despite transformations, the generalized linear model failed to meet assumptions. However, FQI values were higher, thus more typical of undisturbed native prairies, in plots with $C$. sessiliflora $\left(\mathrm{F}_{[1,18]}=15.16, \mathrm{p}=0.0009\right)$. Two outliers, plots without the hemiparasite, have an FQI value closely resembling plots with the hemiparasite. This bias appears to be the cause of failure to meet the assumption of normality.

I used a regression model to express the association between the total percent cover of $C$. sessiliflora present within the plots and the total number of species. The best fit model was a 
polynomial regression $\left(\mathrm{y}=0.8005 \mathrm{x}-0.0247 \mathrm{x}^{2}+21.225 ; \mathrm{F}_{[2,19]}=4.07, \mathrm{p}=0.0339\right)$. This suggests that species richness is maximal at C. sessiliflora cover of about 15\% (Fig. 5).

Pedicularis canadensis. MANOVA was used to analyze the effect of $P$. canadensis presence/absence on the cover and the species richness of graminoids and dicots. Unlike the MANOVA used for $C$. sessiliflora, legumes and forbs were combined into broadleaves in order to meet all assumptions. The presence of $P$. canadensis did not significantly affect total percent coverage of graminoids or broadleaves (Pillai's trace $=0.220, \mathrm{~F}_{[3,16]}=1.5$, $\mathrm{p}=0.2525$; Fig. 6). Also, the total numbers of species of graminoids and broadleaves were not significantly affected by the presence of $P$. canadensis (Pillai's trace $=0.175, \mathrm{~F}_{[3,16]}=1.14$, $\mathrm{p}=0.3647$; Fig. 7).

\section{Soil Nutrients}

Repeated measures MANOVA was used to analyze differences in soil nutrient levels at different distances from the crown. $\mathrm{NO}_{3}$ and $\mathrm{PO}_{4}$ differ significantly as response variables using a $\log _{10}$ transformation (Pillai's trace $=0.964, \mathrm{~F}_{[2,34]}=458.51, \mathrm{P}<0.0001$ ). The identity of the hemiparasite species significantly affected the absorption of ions onto the sampling membranes (Pillai's trace $=1.330, \mathrm{~F}_{[6,70]}=23.16, \mathrm{P}<0.0001$ ). However, each species occurred on a different site and so these differences are likely to be due to local soil characteristics (Fig. 8). Distance from the crown did not significantly affect nutrient levels (Pillai's trace $=0.094, \mathrm{~F}_{[4,32]}=0.83$, $\mathrm{p}=0.5151$ ), indicating that any spatial effect of nutrient input from the hemiparasite litter was not detectable against background levels. The effect of distance from the crown did not differ among species (Pillai's trace $=0.309, \mathrm{~F}_{[12,102]}=0.98, \mathrm{p}=0.4763$ ).

Although distance from the crown was not a significant effect, $C$. sessiliflora showed a trend toward reduced $\mathrm{PO}_{4}$ with increasing distance (Fig. 8). MANOVA of $\mathrm{NO}_{3}$ and $\mathrm{PO}_{4}$ in plots 
with and without $C$. sessiliflora present revealed a significant effect of hemiparasite (Pillai's Trace $\left.=0.373, \mathrm{~F}_{[2,17]}=5.04, \mathrm{p}=0.0191\right)$. Standardized canonical coefficients showed the effect was due to phosphate $\left(\mathrm{NO}_{3}=0.093, \mathrm{PO}_{4}=1.215 ;\right.$ Fig. 9).

\section{Leaf Litter}

The effects of the hemiparasite identity $\left(\mathrm{F}_{[2,55]}=14.83\right.$, $\left.\mathrm{p}<0.0001\right)$, the time the leaves were collected (flowering or senescence) $\left(\mathrm{F}_{[1,56]}=75.23\right.$, $\left.\mathrm{p}<0.0001\right)$, and interaction between the two $\left(\mathrm{F}_{[2,55]}=17.88, \mathrm{p}<0.0001\right)$, all significantly influenced the litter's C:N content. $C$. sessiliflora and $P$. canadensis senesced leaves had significantly lower nitrogen content than leaves at flowering stage while A. grandiflora leaves had no significant difference between the two stages (Fig. 10). 


\section{CHAPTER IV: DISCUSSION}

I studied how root hemiparasites both directly and indirectly influence the surrounding plant community by conducting field observations centered on three hypotheses: hemiparasites alter plant diversity by altering competition through haustoria attachment and parasitism (Keystone Hypothesis); hemiparasites alter soil nutrient/ microbe composition by introducing nutrient-rich leaf litter (Ecosystem Engineer Hypothesis); and hemiparasite life history strategy affects how the hemiparasite affects the soil (Life History Hypothesis). Previous studies that predominantly centered on the annual hemiparasites in the genus Rhinanthus have demonstrated strong effects of root hemiparasites on community structure, with diversity often higher where the hemiparasite is present (Matthies 1995; Bardgett et al. 2006; Watson 2009; Fisher et al. 2013; Fibich et al. 2017). However, the mechanism producing these effects is usually inferred. Several elements of my observational study partially support these hypotheses.

\section{Keystone Species Hypothesis}

The presence of $C$. sessiliflora was associated with increased species richness and a higher FQI, indicating that species associated with this hemiparasite are more typical of a higher quality plant community (i.e., a plant community least disturbed by modern anthropogenic means, Taft 1997). The curvilinear relationship between the total number of species present and the percent cover of the hemiparasite underscores its keystone role. Its correlation with more diverse communities is tied to its abundance, as predicted for a keystone species (Hartley et al. 2015). When $C$. sessiliflora is low in abundance its presence does not have a measurable effect and species that are susceptible to parasitism, but highly competitive, may dominate the community. As this hemiparasite increases in abundance, it may suppress neighboring plants that 
are susceptible to parasitism and lower their ability to compete. Neighboring plants that are more resistant to parasitism may begin to increase in abundance as more susceptible species are suppressed. This can result in maximum species diversity at intermediate levels of hemiparasite abundance. As $C$. sessiliflora continues to increase in abundance parasite-resistant species may dominate, and plant species diversity goes down as susceptible species are further suppressed

I was expecting to find evidence that $P$. canadensis is associated with greater species diversity as it has in past studies (Hedberg et al. 2005). P. canadensis can significantly alter plant communities by decreasing root and shoot development on grass hosts (Borowicz \& Armstrong 2012) as well as dominant forbs (DiGiovanni et al. 2017). While my study did not find the presence of $P$. canadensis associated with altered plant communities, that does not invalidate any past studies that did. How a hemiparasite species affects its community at one study site is not indicative of how that same species can affect all other sites. Several factors might explain my results, which I delve into at a later section.

\section{Ecosystem Engineer Hypothesis}

With the assumption that hemiparasites accumulate excess nutrients in their leaf litter (Quested et al. 2002), I predicted that soil nutrients would be more concentrated immediately surrounding the crown of the hemiparasites compared to further from the hemiparasite or compared to control plots. There was no measurable difference in soil nutrient levels at the crown, $25 \mathrm{~cm}$, or $50 \mathrm{~cm}$ away from the crown of the hemiparasite. This could be due to sampling at a scale that was too small to detect spatial effects of hemiparasite litter. I measured differences in soil content centimeters away from the hemiparasites when I might have been able to detect changes by meters. Short distances away from the hemiparasites were dictated by practicality in 
the field. For example, A. grandiflora were in clusters atop a hill. Meters away from individuals would have either placed the ion strips near another hemiparasite or at a lower elevation down the side of the hill. This is understandable as different plant communities, elevation, and soil type will determine the overall makeup of the soil nutrient levels (Bach et al. 2010, Baer et al. 2010).

High levels of phosphate at all distances from C. sessiliflora indicate higher concentrations at this site. However, when comparing the hemiparasite quadrats with the controls, there are significantly higher soil phosphate levels associated with the hemiparasites. This aligns with past studies that determined that hemiparasites do alter the nutrients in the soil in nutrient-poor sub-arctic regions through its higher decomposition rate from their higher leaf nitrogen and phosphate content (Quested et al. 2002, Quested et al. 2003).

Dasistoma macrophylla experienced almost complete herbivory of the leaves on some of my marked plants by caterpillars I was unable to identify. Some leaves had already fallen to the ground and some skeletonized remains of leaves were still attached at the nodes. The caterpillars probably deposited processed plant material under the plants or nearby but also carried off any nutrients that they absorbed from the leaves. Nonetheless, neither D. macrophylla nor $A$. grandiflora, the other root hemiparasite with trees as hosts, exhibited significant effect on soil nutrient concentration as a function of distance from the crown.

I also assumed that the plant would deposit much of its leaf litter near the crown after senescence. While I did collect nutrient samples at varying distances and examined vegetation in plots in which the hemiparasite was present vs. absent, I did not manipulate the plants in any way, nor did I control for where the hemiparasite may have grown in previous years. The surrounding vegetation density and species, and the inability to control for a legacy effect, were 
uncontrolled variables that could have reduced my ability to detect the effect of the hemiparasites.

\section{Site History}

The site histories of Senger and Eight Oaks may be the key factors in understanding my results for $C$. sessiliflora and $P$. canadensis, respectively. The Senger site is a 2015 restored prairie planting with $C$. sessiliflora populations growing on sandy hills. The Eight Oaks planting is a mixture of silty loam that is poorly drained soil and was planted in the 1990's. Timing of planting, mix of species at planting, soil composition, and recent weather events may have played a role in the responses to parasitism.

Castilleja sessiliflora is located on the sandy hills of the Senger unit that was planted during November of 2015 with dry and dry-mesic hand-picked (by seasonal field technicians, sourced from other units on the preserve) seed mixes together totaling 217 species. The prairie, a relatively young restoration of a former corn field, had a mixture of early and later-successional plant species that were recorded in the vegetation surveys. Tallgrasses that could be highly susceptible to parasitism such as Andropogon gerardii and Sorgastrum nutans did not yet have a dominating presence. Pedicularis canadensis is located in the mesic Eight Oaks unit that was first planted in the 1990's with a less diverse forb seed mix and a higher concentration of tallgrasses (E. Bach, personal comm.), a common management method used when financial resources are low. Subsequently, the hemiparasite was planted in 2006-2008 as part of an experiment.

Younger sites, such as Senger, that have been disturbed more recently have fewer large soil aggregates whereas soil that has been undisturbed has more, larger soil aggregates. These 
aggregates are known to anchor macro- and micronutrients in place, allowing for less runoff. The older a planting is, the more homogenous the soil nutrient profile can be. Because Senger was planted recently, minor differences in soil nutrients may be more readily detected. Also, Eight Oaks has a higher clay content than Senger, and clay is responsible for poorer water drainage. Clay is also known to trap charged particles, preventing runoff of macro- and micronutrients. Soil with low clay content and more sand, such as Senger, is more susceptible to runoff. (Bach et al. 2010, Baer et al. 2010). Consequently, effects of litter on soil nutrients may be more pronounced on Senger.

Both Senger and Eight Oaks units were burned with prescribed fires in early Spring 2019. The act of burning the leaf litter could negate any localized influence on soil nutrients by more evenly distributing the litter across a wider area. Eight Oaks was also regularly visited and grazed by the bison herd, which could have skewed the vegetation survey results but making a few grasses unidentifiable and introducing nutrient or microbe influence into the soil.

The summer and fall of 2019 had a higher-than-average rainfall, resulting in occasional flooding in poorly drained soils of Eight Oaks. This may have had two effects that blunted the impact of $P$. canadensis. Hemiparasites have greater influence on their plant community when resources are low by siphoning them from host plants, thus lowering the hosts' competitive ability (Matthies 1995). Flooding and burning may have redistributed nutrients such that any litter effects were removed. Also, the higher rainfall would have provided more than enough water to satiate haustoria-infested plants, and this could have dampened the parasitic effects of P. canadensis on their hosts. 


\section{Life History Hypothesis}

Because I was unable to obtain senesced leaves from both the annual hemiparasites in my study, I cannot make an in-depth comparison of annual and perennial hemiparasites using my data alone. The comparisons that I was able to make using the results from my perennial leaves can still be useful, just not for my life history hypothesis. The senesced leaves have a higher C:N content than flowering-stage leaves for the two hemiparasites that are known to parasitize herbaceous plants (Fig. 10). This is an indication that the parasites are translocating nitrogen from its leaves presumably to its roots. A. grandiflora senesced leaves do not appear to have lost a significant amount of nitrogen. This could indicate that the hemiparasite can afford to lose nitrogen. While A. grandiflora do not have above-ground biomass active outside the growing season, its arboreal hosts do. There is a possibility that the trees have a large enough source of xylem flow in the spring when stored minerals and sugars are translocated to the shoot that negates the need of the hemiparasites to store resources.

In order to support the life history hypothesis proposed in my research, I need access to more hemiparasites. The best method would be to grow multiple hemiparasites under common conditions in order to minimize variation. However, a quick comparison of a few past studies shows an interesting pattern (Fig. 11). The least square means of the three perennial hemiparasites' senesced leaves used in this study range between 1.01-1.28 \% N. Subarctic perennial hemiparasites used by Quested et al. (2002) have a range of 1.48-2.51\% N, and annual hemiparasites have a range of $2.04-4.1 \% \mathrm{~N}$. The shorter-lived species appear to have a larger nitrogen content than the perennials. All the hemiparasites' senesced leaves had lower C:N content than non-parasitic herbaceous plants such as native Midwestern prairie perennials 
Solidago canadensis and Schyzacharium scoparium (61 and $90 \mathrm{gC} \mathrm{gN-1} \mathrm{respectively,} \mathrm{Schuster}$ 2016).

\section{Use of Root Hemiparasites in Restoration Practices}

Prairie grasslands are an endangered ecosystem that once dominated the Midwestern region of the United States (Samson \& Knopf 1996). With so few remnant prairies left, prairie restoration is viewed as an important means for restoring habitat and ecosystem services (Corbin et al. 2004, Rook et al. 2011). In order to reconfigure a landscape to fit the identity of a prairie, conservationists rely on essential components of how a prairie was maintained prior to European settlement. All prairies require infrequent disturbance in order to halt succession and ensure vegetative heterogeneity (Hamman et al. 2011, Rook et al. 2011). Although disturbance by fire and grazing have long been used to restore and maintain grasslands, parasitic plants also produce heterogeneity (Spasojevic \& Suding 2011, Borowicz et al. 2019). The hemiparasites have been included in restored prairies, at times highly sought after due to some species' ability to decrease the amount of dominant grasses (Henderson 2003, Cameron et al. 2005).

Due to the relatively inexpensive cost of adding them to a seed mix, the use of root hemiparasites in ecological restoration can be appealing to land managers who might not have reliable use of prescribed burning or access to grazers. Past studies outside the United States have recommended the use of hemiparasites. Fibich et al. (2017) recommended the use of Rhinanthus species to increase plant diversity. However, in reality, hemiparasites do not serve as the end solution. Just because a hemiparasite is native in the area the restoration is taking place does not mean it will necessarily yield the desired results. For instance, Decleer et al. (2013) believe that reintroduction of the endangered hemiparasite Pedicularis palustris can be a helpful 
tool in restoration management in fen-meadows, but limited to the hemiparasite's specific habitat and combined with additional management practices, such as mowing. A land manager seeking to control aggressive tallgrasses in an effort to increase forb diversity should not solely heavily overseed with a hemiparasite. A keystone species in excess will not be able to balance the usually competitive plant species, in this case being susceptible host plants, with the less competitive, or the parasite-resistant plants. If the hemiparasites' presence is too much, the resistant species could dominate and crowd out the hosts. The hemiparasites will also have a stronger effect in a nutrient-poor planting, which could mean they shouldn't be planted close to areas where runoff accumulates such as close to roads. Carefully thought-out reintroduction of root hemiparasites is needed for a successful restoration, such as not adding the seeds to the main mixes in order to separately add by hand. 


\section{CHAPTER V: CONCLUSION}

The role of root hemiparasites in Illinois, especially tallgrass prairies, is still being determined. What is evident is a that data from a single year is not enough to complete their profile. A comprehensive long-term study across multiple sites would be the best method. Root hemiparasites as a restoration tool should be considered, but not as a final solution. Land managers should be cautioned against heavily overseeding these species into their seed mix lest the overbearing presence of hemiparasites proves counterproductive to the original management goal. Regardless of their potential as grass and dominant forb control, root hemiparasites are original members of native plant communities and should be included in restoration plantings. 


\section{REFERENCES}

Abrahamson W (1979) Patterns of Resource Allocation in Wildflower Populations of Fields and Woods. American Journal of Botany 66:71-79.

Ameloot E, Verheyen K, Hermy H (2005) Meta-analysisof standing crop production by Rhinanthus spp. and its effecton vegetation structure. Folia Geobotanica 40:289-310.

Bach EM, Baer SG, Meyer CK, Six J (2010) Soil texture affects soil microbial and structural recovery during grassland restoration. Soil Biology and Biochemistry. Dec $1 ; 42(12): 2182-91$.

Baer SG, Meyer CK, Bach EM, Klopf RP, Six J (2010) Contrasting ecosystem recovery on two soil textures: implications for carbon mitigation and grassland conservation. Ecosphere. Jul;1(1):1-22.

Bardgett RD The biology of soil: a community and ecosystem approach. Oxford university press; 2005 Jun 2.

Bardgett RD, Smith RS, Shiel RS, Peacock S, Simkin JM, Quirk H, Hobbs PJ (2006) Parasitic plants indirectly regulate below-ground properties in grassland communities. Nature. 439: 969-972.

Berendse F, Jonasson S (1992) Nutrient use and nutrient cycling in northern ecosystems. In: Chapin FS, Jefferies RL, Reynolds JF, Shaver GS, Svoboda J (eds) Arctic ecosystems in a changing climate, an ecophysiological perspective. Academic Press, San Diego, 337356.

Borowicz VA, Armstrong JE (2012) Resource limitation and the role of a hemiparasite on a restored prairie. Oecologia. Jul 1;169(3):783-92. 
Callaghan TV, Jonasson S (1995) Arctic terrestrial ecosystems and environmental change. Philos Trans $R$ Soc Lond 352:259-276

Cameron DD, Hwangbo J, Keith AM, Geniez J, Kraushaar D, Rowntree J, Seel WE (2005) Interactions between the hemiparasitic angiosperm Rhinanthus minor and its hosts: from the cell to the ecosystem. Folia Geobotanica 40:217-229

Corbin JD, D'Antonio CM, Bainbridge SJ (2004) Tipping the balance in the restoration of native plants: experimental approaches to changing the exotic: native ratio in California grassland. Pages 154-179. In: Gordon MS, Bartol SM (eds) Experimental approaches to conservation biology. University of California Press, Berkeley, CADemey A, Ameloot E, Staelens J, De Schrijver A, Verstraeten G, Boeckx P, Hermy M, Verheyen K (2013) Effects of two contrasting hemiparasitic plant species on biomass production and nitrogen availability. Oecologia. Sep 1;173(1):293-303.

Department of Botany, Wisconsin State Herbarium, University of Wisconsin-Madison (2020) Taxa http://wisflora.herbarium.wisc.edu/taxa/ (accessed 11 Jun 2020).

DiGiovanni JP, Wysocki WP, Burke SV, Duvall MR, Barber NA (2017) The role of hemiparasitic plants: influencing tallgrass prairie quality, diversity, and structure. Restoration Ecology. 25(3): 405-413.

Dixon KW, Pate JS, Bailey WJ (1980) Nitrogen nutrition of the tuberous sundew Drosera erythrorhiza Lindl. with special reference to catch of arthropod fauna by its glandular leaves. Australian Journal of Botany. 28(3):283-97.

Ellis R, Roberts E (1980) The Influence of Temperature and Moisture on Seed. Viability Period in Barley (Hordeum distichum L.). Annals of Botany. 45:31-37. 
Fibich P, Lepš J, Chytrý M, Těšitel J (2017) Root hemiparasitic plants are associated with high diversity in temperate grasslands. Journal of Vegetation Science. Jan;28(1):184-91.

Fisher JB, Phoenix GK, Childs DZ, Press MC, Smith SW, Pilkington MG, Cameron DD (2013) Parasitic plant liter input: a novel indirect mechanism influencing plant community structure. New Phytol. 198:222-231.

Gibson CC, Watkinson AR (1989) The host range and selectivity of a parasitic plant: Rhinanthus minor L. Oecologia 78.3: 401-406.

Hamman ST, Dunwiddie PW, Nuckols JL, McKinley M (2011) Fire as a restoration tool in Pacific Northwest prairies and oak woodlands: challenges, successes, and future directions. Northwest Science 85:317-328

Hansen RA (2000) Diversity in the decomposing landscape. Invertebrates as Webmasters in Ecosystems, ed. DC Coleman and PE Hendrix, 203-219.

Harper J, Ogden J (1970) The Reproductive Strategy of Higher Plants: I. The Concept of Strategy with Special Reference to Senecio Vulgaris L. The Journal of Ecology. 58:681698.

Hartley SE, Green JP, Massey FP, Press MC, Stewart AJ, John EA (2015) Hemiparasitic plant impacts animal and plant communities across four trophic levels. Ecology. Sep;96(9):2408-16.

Hedberg AM, Borowicz VA, Armstrong JE (2005) Interactions between a hemiparasitic plant, Pedicularis canadensis L.(Orobanchaceae), and members of a tallgrass prairie community. The Journal of the Torrey Botanical Society Jul;132(3):401-10. 
Hedley MJ, Stewart JW, Chauhan B. Changes in inorganic and organic soil phosphorus fractions induced by cultivation practices and by laboratory incubations (1982) Soil Science Society of America Journal. Sep;46(5):970-6.

Henderson RA (2003) Are there keystone plant species driving diversity in Midwest prairies? Pages 63-66. In: Fore S (ed) Promoting prairie: Proceedings of the 18th North American prairie conference. Truman State University, Kirksville, Missouri

Jiang F, Jeschke WD, Hartung W (2003) Water flows in the parasitic association Rhinanthus minor/Hordeum vulgare. J Exp Bot 54:1985-1993.

Lamont B (1983) Mineral nutrition of mistletoes. In: Calder DM, Bernhardt P (eds) The biology of mistletoes. Academic Press, New York, pp 185-204

Lloyd FE (1942) The carnivorous plants. Chronica Botanica, Vol. 9. Waltham, Massachusetts. Lovett Doust J (1980) A comparative study of life history and resource allocation in selected Umbelliferae. Biological Journal of the Linnean Society. 13:139-154.

Mann WF, Musselman LJ (1981) Autotrophic Growth of Southern Root Parasites. The American Midland Naturalist 106(1):203-205.

Matthies D (1995) Parasitic and competitive interactions between the hemiparasites Rhinanthus serotinus and Odontities rubra and their host Medicago sativa. Journal of Ecology. $83: 245-251$.

Molano-Flores B, Feist MA, Whelan CJ (2003) Seed Germination, Seedling Survivorship, and Host Preference of Agalinis auriculata (Michx.) Blake (Orobanchaceae), and Illinois, USA, Threatened Species. Natural Areas Journal, 23(2):152-157.

Musselman LJ, Press MC (1995) Introduction to parasitic plants. Pp. 1-13 in M. C. Press \& J. D. Graves (editors), Parasitic Plants. Chapman and Hall, London. 
Paine, RT (1966) Food web complexity and species diversity. American Naturalist 100, 65-75.

Pate JS (1995) Mineral relationships of parasites and their hosts. In: Press MC, Graves JD (eds) Parasitic plants. Chapman and Hall, London, 80-102.

Piehl MA (1962) The parasitic behavior of Dasistoma macrophylla. Rhodora, 64(760):331-336.

Plant Finder Staff, Missouri Botanical Gargen (2020) Plant Finder http://www.missouribotanicalgarden.org/plantfinder/plantfindersearch.aspx (accessed 11 Jun 2020).

Press MC, Phoenix GK (2005) Impacts of parasitic plants on natural communities. New Phytologist 166:737-751.

Press MC, Scholes JD, Watling JR (1999) Parasitic plants: physiological and ecological interactions with their hosts. In: Press, M.C., J.D. Scholes, J.R. Watling, eds. Physiological Plant Ecology. Oxford, UK: Blackwell Science. 175-197.

Pywell RF, Bullock JM, Walker KJ, Coulson SJ, Gregory SJ, Stevenson MJ (2004) Facilitating grassland diversification using the hemiparasitic plant Rhinanthus minor. Journal of Applied Ecology 41:880-887.

Quested HM, Press MC, Callaghan TV, Cornelissen JHC (2002) The hemiparasitic angiosperm Bartsia alpina has the potential to accelerate decomposition in sub-arctic communities. Oecologia 130:88-95.

Quested HM, Press MC, Callaghan TV, (2003) Litter of the hemiparasite Bartsia alpina enhances plant growth: evidence for a functional role in nutrient cycling. Oecologia, 135(4):606-614. 
Rook EJ, Fischer DG, Seyferth RD, Kirsch JL, LeRoy CJ, Hamman S (2011) Responses of prairie vegetation to fire, herbicide, and invasive species legacy. Northwest Science 85:288-302Schneider MJ, and Stermitz FR (1990) Uptake of host plant alkaloids by root parasitic Pedicularis species. Phytochemistry. 29(6): 1811-1814.

Schuster MJ (2016) Increased rainfall variability and N addition accelerate litter decomposition in a restored prairie. Oecologia. Mar 1;180(3):645-55.

Spasojevic M, Suding K (2011) Contrasting effects of hemiparasites on ecosystem processes: can positive litter effects offset the negative effects of parasitism? Oecologia. 165:193200.

Suding KM, Harpole WS, Fukami T, Kulmatiski A, MacDougall AS, Stein C, van der Putten WH (2013) Consequences of plant-soil feedbacks in invasion. Journal of Ecology. 101:298-308.

Taft, J.B., Wilhelm, G.S., Ladd, D.M. and Masters, L.A., 1997. Floristic quality assessment for vegetation in Illinois, a method for assessing vegetation integrity (p. 29). Westville, Illinois: Illinois Native Plant Society.

USDA, NRCS. 2020. The PLANTS Database (http://plants.usda.gov, 11 June 2020). National Plant Data Team, Greensboro, NC 27401-4901 USA.

Verhoeven JTA, Schmitz MB (1991) Control of plant growth by nitrogen and phosphorus in mesotrophic fens. Biogeochemistry 12:135-148.

Wang YP, Houlton BZ, Field CB (2007) A model of biogeochemical cycles of carbon, nitrogen, and phosphorus including symbiotic nitrogen fixation and phosphatase production. Global Biogeochemical Cycles 21:GB1018. 
Watson DM (2009) Parasitic plants as facilitators: more dryad than dracula? Journal of Ecology 97:1151-1159

Wilhelm G, Rericha L (2017) Flora of the Chicago Region: A floristic and ecological synthesis. Indianapolis, Indiana, USA: Indiana Academy of Science. 


\section{APPENDIX A: TABLES}

Table 1. Hemiparasite species and experiments in which they were included.

\begin{tabular}{|c|c|c|c|c|c|}
\hline \multirow{3}{*}{ Species } & \multirow{3}{*}{ Life History } & \multicolumn{4}{|c|}{ Hypotheses tested } \\
\hline & & \multirow{2}{*}{$\begin{array}{l}\text { Keystone } \\
\text { Species }\end{array}$} & \multirow{2}{*}{$\begin{array}{c}\text { Ecosystem } \\
\text { Engineer }\end{array}$} & \multicolumn{2}{|c|}{ Life History } \\
\hline & & & & Flowering & Senescing \\
\hline Agalinis tenuifolia & Annual & & & $\mathrm{X}$ & \\
\hline Aureolaria grandiflora & Perennial & & $X$ & $\mathrm{X}$ & $\mathrm{X}$ \\
\hline Castilleja sessiliflora & Perennial & $\mathrm{X}$ & $\mathrm{X}$ & $\mathrm{X}$ & $\mathrm{X}$ \\
\hline Dasistoma macrophylla & Annual & & $X$ & $X$ & \\
\hline Pedicularis canadensis & Perennial & $X$ & $X$ & $\mathrm{X}$ & $X$ \\
\hline
\end{tabular}




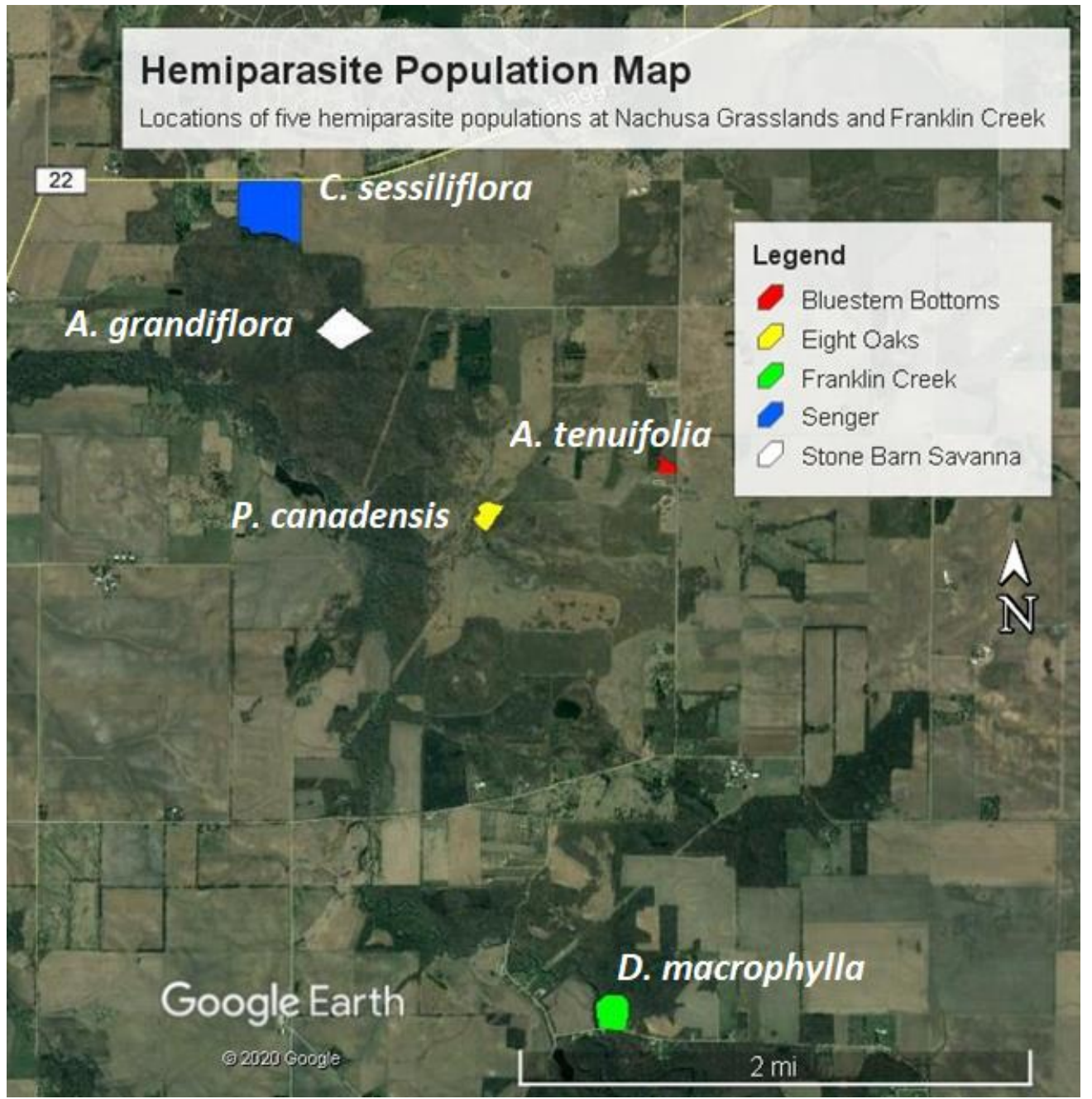

Fig. 1 Map of five hemiparasite populations located throughout Nachusa Grasslands and Franklin Creek State Natural Park. Source: GoogleEarth 


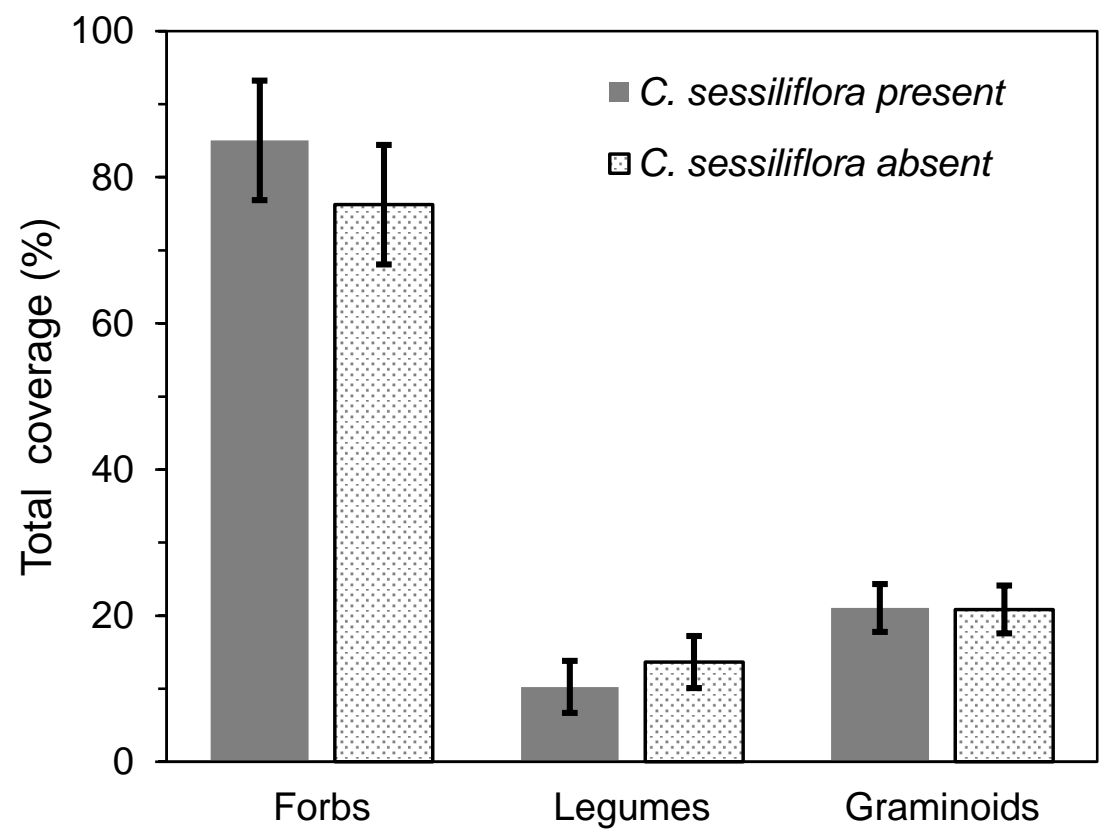

Fig. 2 Least Square Means $( \pm$ SE) values of total percent coverage of plant species functionally classified as forbs, legumes, and graminoids within plots with $C$. sessiliflora and without $C$. sessiliflora. No significant difference was detected in any of the three functional plant groups. $n=10$ for each treatment. 


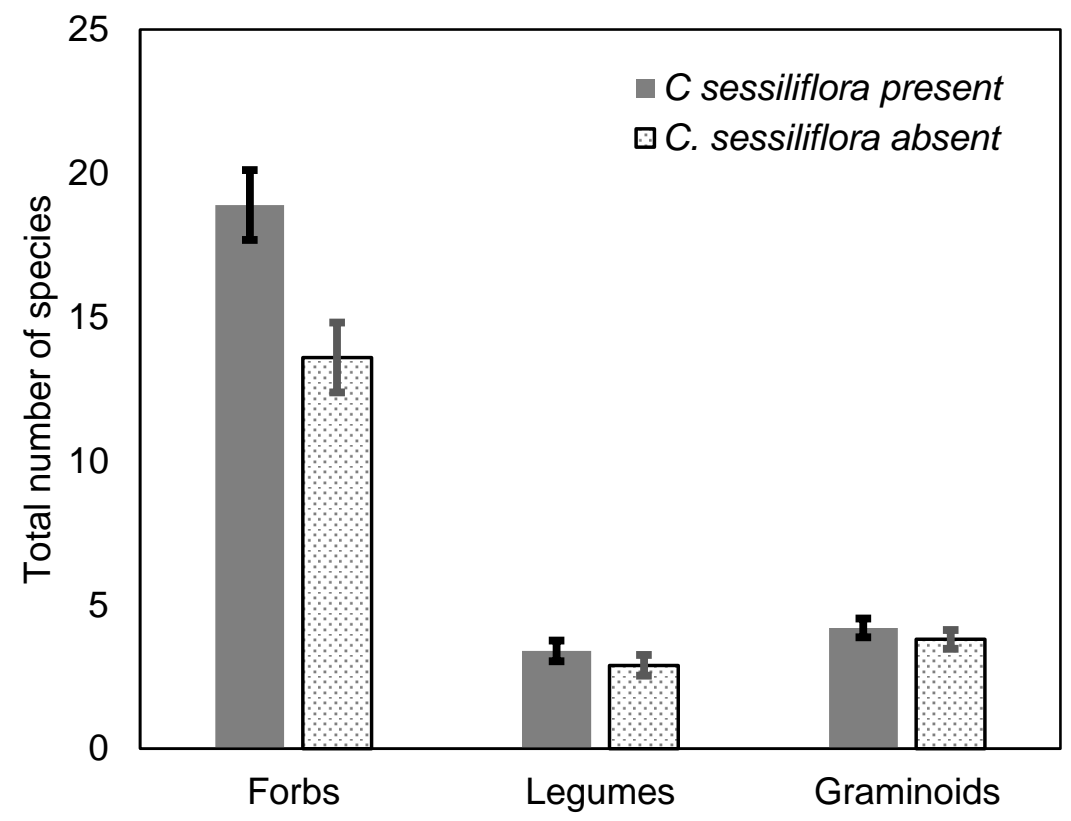

Fig. 3 Least Square Means $( \pm$ SE) values for total number of plant species grouped by the three functional groups: non-legume forbs, nitrogen-fixing legumes, and graminoids. No significant difference was found for legumes or graminoids, but forbs were different with a greater number of forb species found in the $C$. sessiliflora plots than the control. $n=10$ for each treatment. 


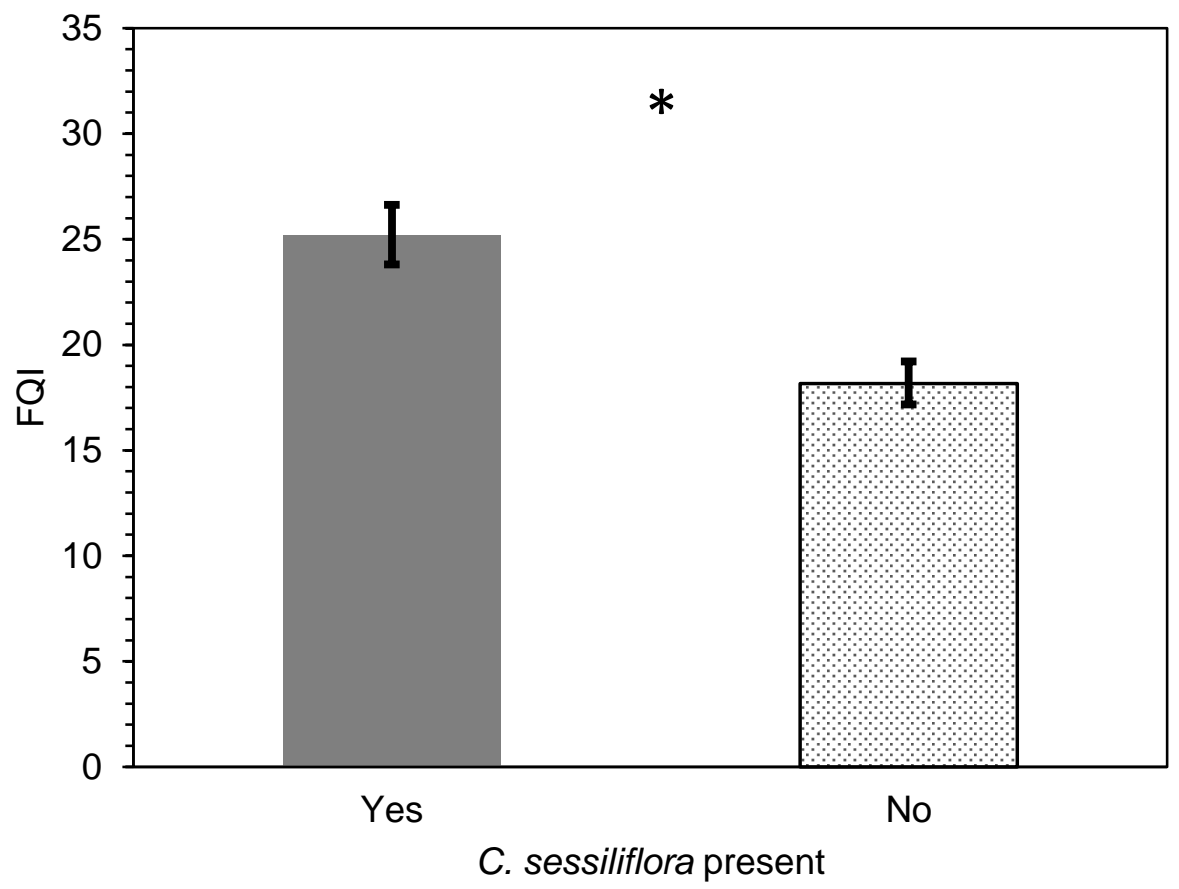

Fig. 4 Least Square Means ( \pm SE) values of the Floral Quality Indices (FQI) reported for $C$. sessiliflora plots. The FQI was significantly higher in plots with the hemiparasite than without. $n=10$ for each treatment. No transformations met the assumptions of normality. Inverse log transformation came the closest to meeting assumptions $\left(\mathrm{F}_{[1,18]}=18.8\right.$, $\mathrm{p}=0.0004)$. 


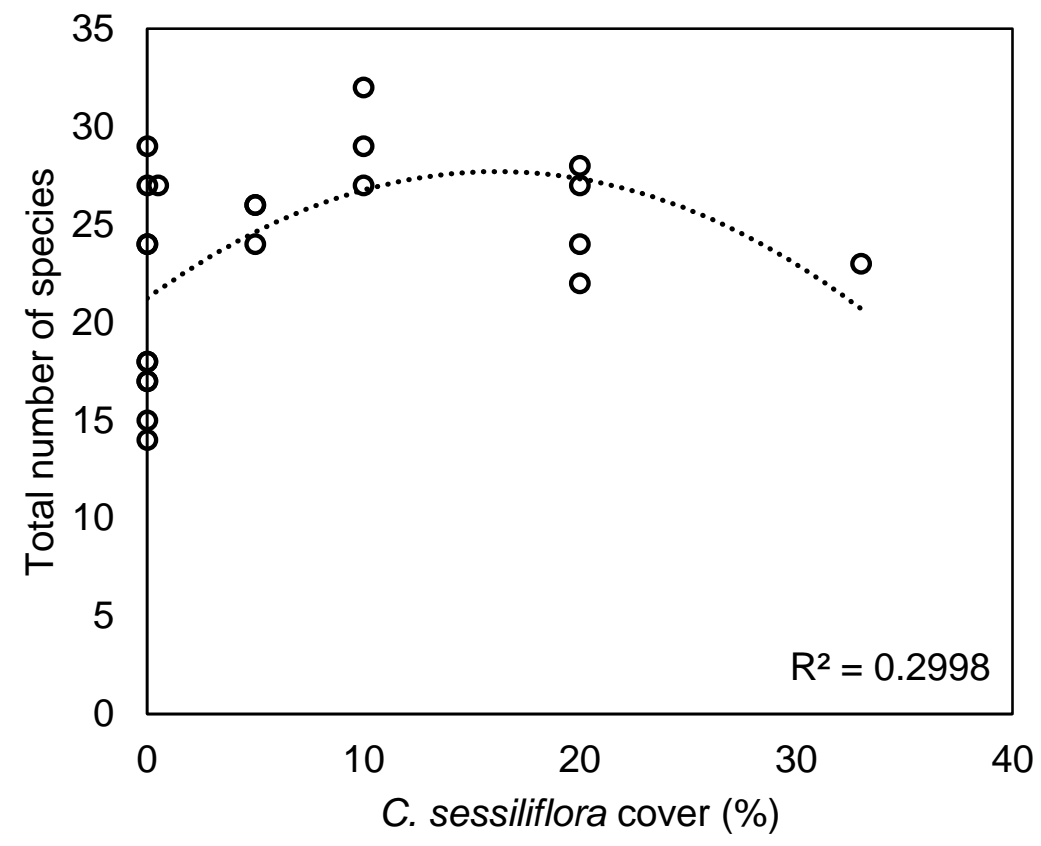

Fig. 5 A polynomial regression $\left(y=-0.0247 x^{2}+0.8005 x+\right.$ 21.225) of the total number of species present against the total percent coverage of $C$. sessiliflora. The plots absent of the hemiparasite are the control plots ( 20 plots in total). There is a significant correlation between the two variables $\left(\mathrm{F}_{[2,19]}=4.07\right.$, $\mathrm{P}=0.0339$ ). 


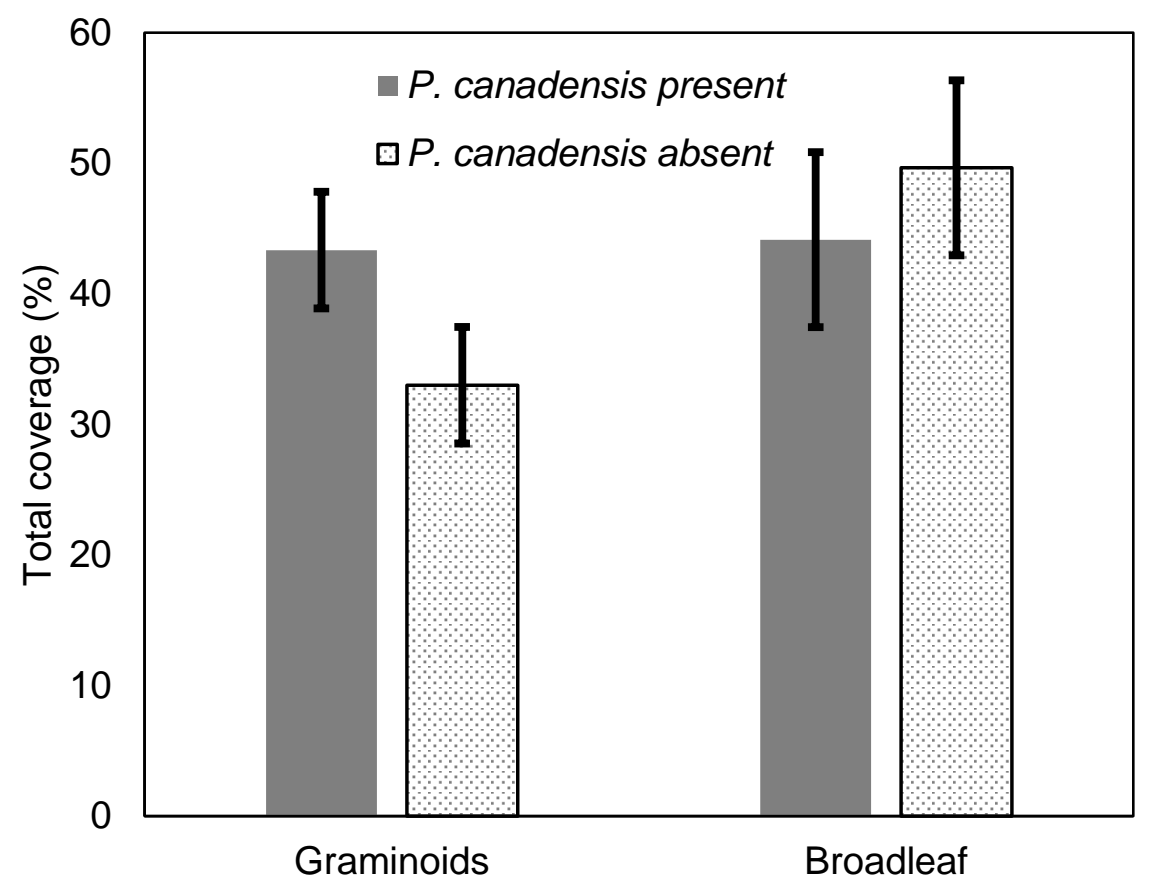

Fig. 6 Least Squares Means ( \pm SE) of total percent coverage of plant species functionally classified as graminoids and broadleaves within plots with $P$. canadensis and without $P$. canadensis. No significant difference was detected in the two functional plant groups. $n=10$ for each treatment. 


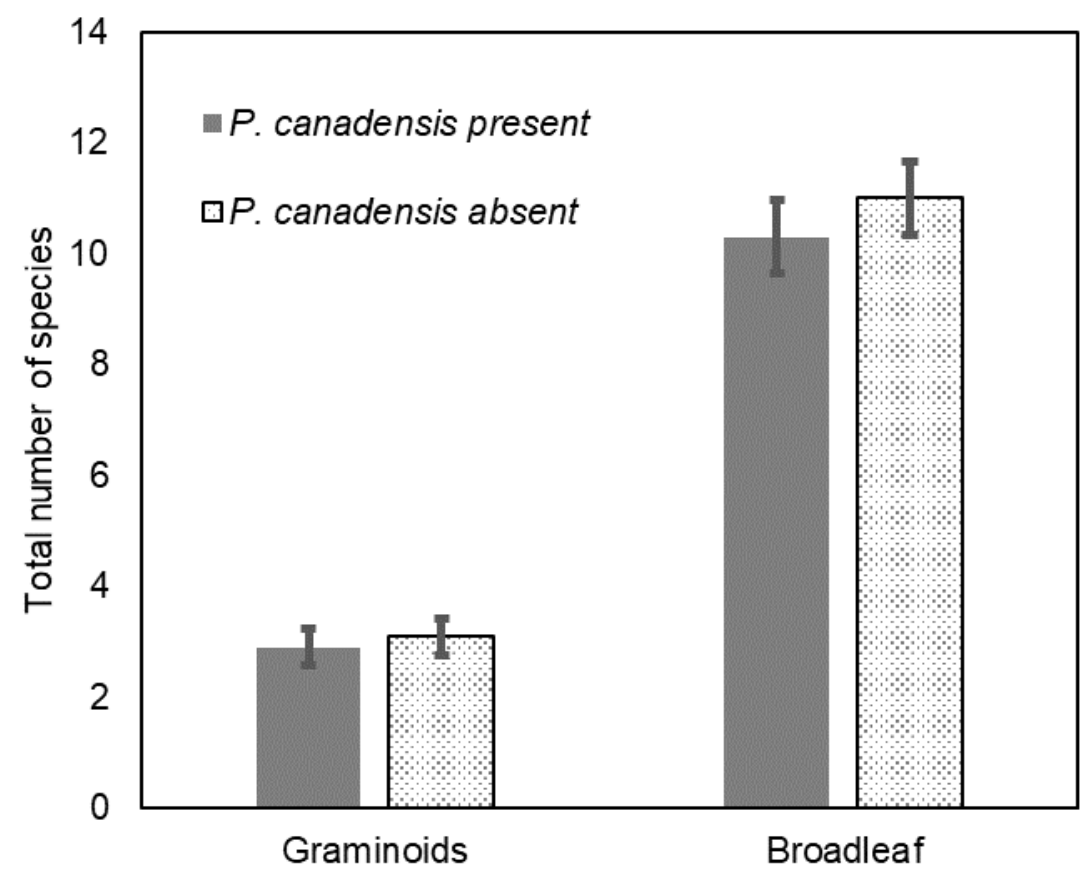

Fig. 7 Least Square Means $( \pm$ SE) values for total number of plant species grouped by two functional groups: graminoids and broadleaf plants. No significant difference was found for the functional groups based on the presence or absence of $P$. canadensis. $n=10$ for each treatment. 


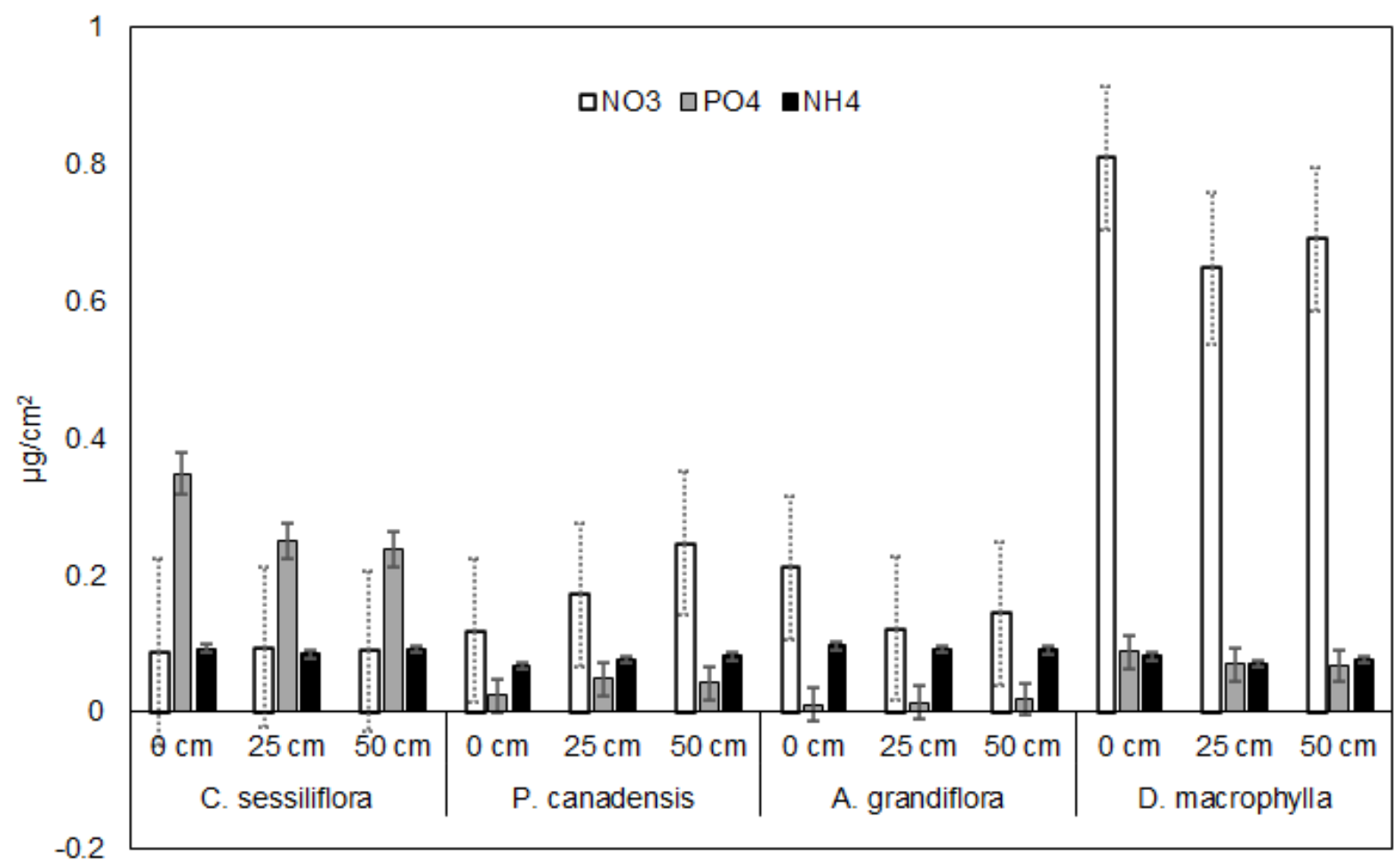

Fig. 8 Average nutrients absorbed $\left(\mu \mathrm{g} / \mathrm{cm}^{2}\right)$ at the base of the leaf canopy of the hemiparasite $(0 \mathrm{~cm}), 25 \mathrm{~cm}$ from the canopy, and $50 \mathrm{~cm}$ away within experimental plots. 


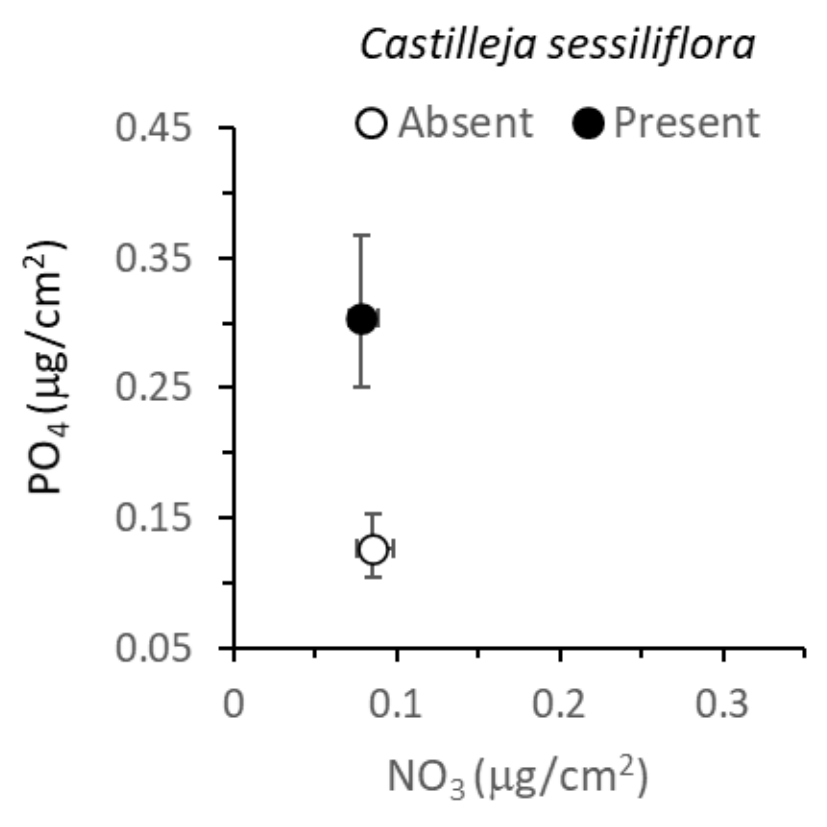

Fig. 9 Least Square Means $( \pm$ SE) values for soil nitrate and phosphate levels in plots with vs. without $C$. sessiliflora. Log-transformed phosphate levels were significantly greater $(P=0.0135, n=20)$ within $C$. sessiliflora plots. Ammonium (NH4) levels were dropped from the analysis due to destroyed materials at site. 


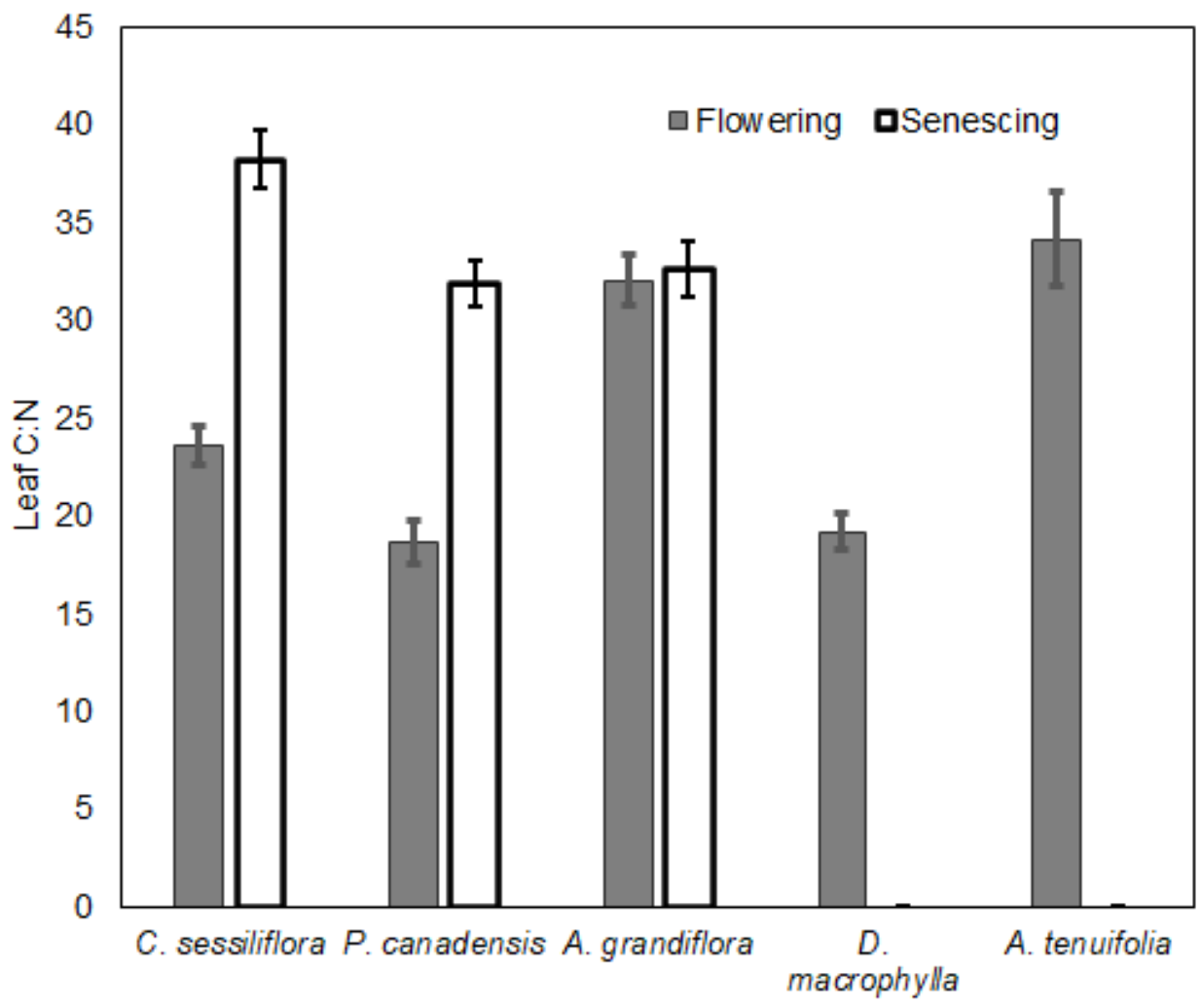

Fig. 10 Average values for Carbon:Nitrogen content in hemiparasite leaves while each species is flowering and upon senescence, when the leaves begin to fall off the stem. Senesced leaves for the two annuals, D. macrophylla and A. tenuifolia, could not be acquired. 
(a)

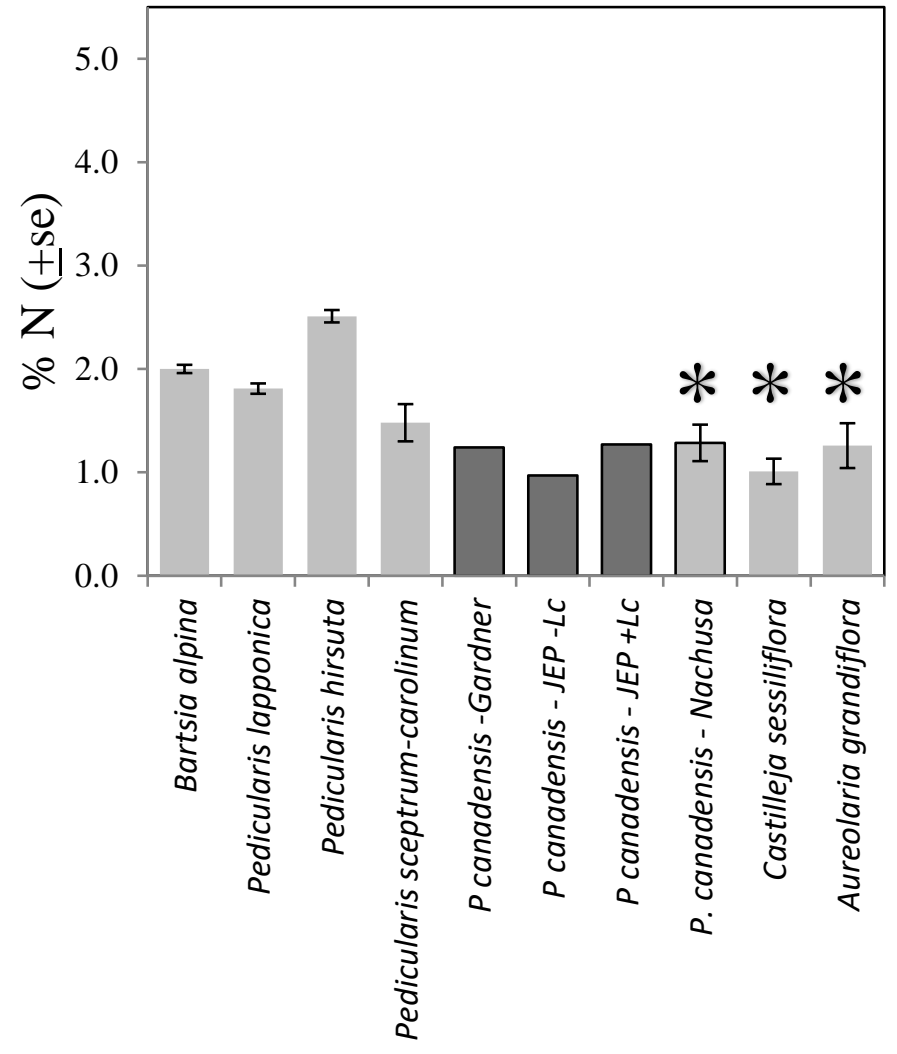

(b)

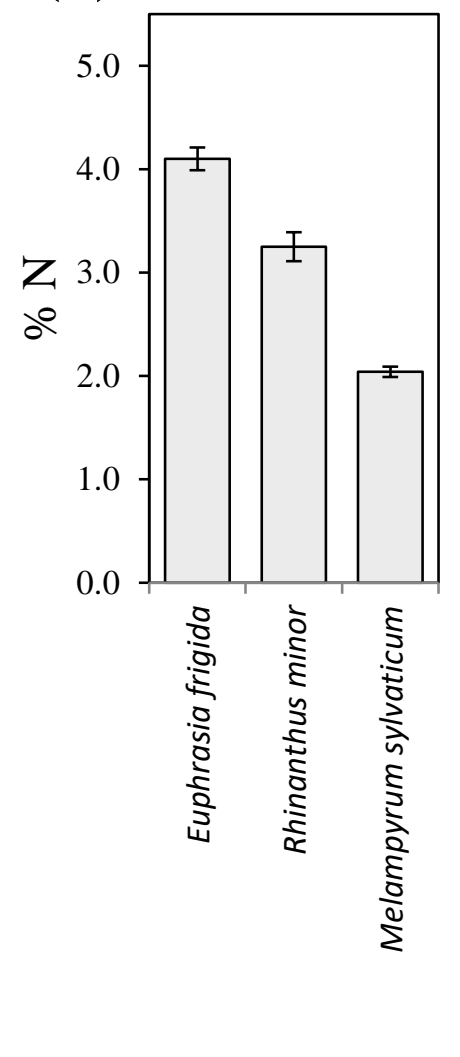

Fig. 11 Percent nitrogen content found in leaf litter from (a) perennial and (b) annual hemiparasitic species. Asterisks indicate leaf litter data from this experiment. Other values were obtained from past studies focusing on hemiparasites nutrient data (Quested et al. 2002). 